\title{
Emotions and foreign direct investment: a theoretical and emperical exploration
}

Citation for published version (APA):

van de Laar, M. M., \& de Neubourg, C. R. J. (2004). Emotions and foreign direct investment: a theoretical and emperical exploration. METEOR, Maastricht University School of Business and Economics. METEOR Research Memorandum No. 013 https://doi.org/10.26481/umamet.2004013

Document status and date:

Published: 01/01/2004

DOI:

10.26481/umamet.2004013

Document Version:

Publisher's PDF, also known as Version of record

\section{Please check the document version of this publication:}

- A submitted manuscript is the version of the article upon submission and before peer-review. There can be important differences between the submitted version and the official published version of record.

People interested in the research are advised to contact the author for the final version of the publication, or visit the DOI to the publisher's website.

- The final author version and the galley proof are versions of the publication after peer review.

- The final published version features the final layout of the paper including the volume, issue and page numbers.

Link to publication

\footnotetext{
General rights rights.

- You may freely distribute the URL identifying the publication in the public portal. please follow below link for the End User Agreement:

www.umlib.nl/taverne-license

Take down policy

If you believe that this document breaches copyright please contact us at:

repository@maastrichtuniversity.nl

providing details and we will investigate your claim.
}

Copyright and moral rights for the publications made accessible in the public portal are retained by the authors and/or other copyright owners and it is a condition of accessing publications that users recognise and abide by the legal requirements associated with these

- Users may download and print one copy of any publication from the public portal for the purpose of private study or research.

- You may not further distribute the material or use it for any profit-making activity or commercial gain

If the publication is distributed under the terms of Article $25 \mathrm{fa}$ of the Dutch Copyright Act, indicated by the "Taverne" license above, 


\section{Emotions and foreign direct investment: a theoretical and empirical exploration Mindel van de Laar and Chris de Neubourg}

Abstract:

Emotions are largely absent in economic models. However, many theories still cease to explain the actual situations. We combine regular microeconomic theory with emotions. We focus on an FDI decision of a firm, including both business-economics and emotional variables in the firms decision-making process.Theoretically, emotions are included in a utility maximization model, by not only considering the utility of the firm but also the utility of the decision-maker. Empirically, the presence of emotions in FDI decisionmaking is tested using a sample of Dutch enterprises that considered an investment in Central or Eastern Europe between 1990 and 2000.

\section{Key results:}

Adding emotions to economic theory can enhance our understanding of the reality. The empirical results showed that emotions are important in economic decision-making. The presence of positive emotions increased the chance of Dutch firms to engage in an FDI in Central and Eastern Europe.

\section{JEL codes:}

A13, D21, F21, F23

Drs. Mindel van de Laar and Prof. Dr. Chris de Neubourg both work at Maastricht University, Faculty of Economics and Business Administration, Department of Economics, P.O. Box 616, 6200 MD Maastricht, the Netherlands. Email: M.vandelaar@algec.unimaas.nl

We thank Dr. Christiane Schwieren, Prof. Gerard Pfann, Dr. Piet Keizer, the participants from the "International Business in Transition Economies conference, Vilnius 2002 and the anonymous referees from the Management International Review for their useful comments. 


\section{Introduction}

Unlike Dr Spock cruising the Galaxy in his Voyager, most humans are not stripped of their emotions when making decisions. But equally most humans do not possess Dr. Spock's information processing capacities when making choices (Earl, 2001). This is nevertheless how economic analysis models human decisions. Standard rational choice models and the bulk of empirical studies on microeconomic choice behavior use a rational choice model wherein little room is left for emotions to play a role, let alone a decisive one. The skills required to select and to handle the information that is needed to guarantee the rationality of the choice, are assumed to be abundantly available among human decision-makers. This assumption is not different in the study of foreign direct investment (FDI ) decisions. The complicated processes leading to a decision either to invest or not and where to invest (geographically) are notoriously difficult to model and the last thing that we need is more complication in terms of emotions playing a role. Direct investmentdecisions are assumed to be based on estimates of the Net Present Values of all investment options and the final decision on whether or not to proceed with the investment in a particular country is assumed to be based on the ranking of all options (including the negative one of not to invest) in terms of their estimated Net Present Value.

When preparing a survey on investment-decisions of Dutch firms in Central and Eastern Europe and Central Asia we explored the many reasons that might have played a role during open interviews with investors. During these discussions, approximately half of the respondents implied that "emotional" elements played a role in making final choices both regarding the decision to invest and the final choice of the country. Considerations such as the fact that the manager had participated in an exchange program during his/her study in that specific country, the fact that the partner of (one of) the owner(s) holds citizenship of the host country or that a personal acquaintance asked the Dutch firm to take over the foreign business, were among the important factors quoted to have been decisive elements in the decision process. These considerations seem far away from the algorithms of pure rational choice, but the question is whether they are.

In this paper we explore theoretically how emotions can be seen as compliments to rational choice processes and illustrate empirically that emotional factors do play a role in foreign direct investment-decisions. Section two includes a description of the economic decision-making literature including emotions and a framework that can be used to include emotions in investment-decisions. In section three a simple utility maximizing decisionmaking model will be described, with the specifications on how to include emotions. Section four provides empirical evidence that emotions are an influencing factor in the FDI decision-making process, using the data from a survey among Dutch enterprises considering a foreign direct investment in Central and Eastern Europe. The paper concludes that adding emotions to FDI theory enhances our understanding of the actual decision processes.

\section{Emotions and investment-decision-making}

\subsection{Rationality and bounded rationality}

Recent contributions in investment-decision-making literature have expanded the commonly used Net Present Value or Utility based models of foreign direct investment by including the effects uncertainty and irreversibility of investments (often referred to as the option literature, Dixit and Pindyck, 1994; Trigeorgis, 1996). In these more sophisticated models pure rationality including full information is still very dominant, like in many areas in economics. ${ }^{i}$ Within the economic literature there are several models or theories that question those rationality assumptions, like the theory of bounded rationality. Given rational choice, firms may not be utility (profit) maximizing and full information is absent. Decision-making under uncertainty is hard, since predicting the future is hard and humans face cognitive limitation. Those critiques are largely accepted and theory is adjusted based on empirical evidence (Simon, 1997) ${ }^{\text {ii }}$. The decision-making solution bounded rationality offers is that firms do not attempt to search for all investment possibilities but choose a for all parties satisficing solution (Simon, 1997).

Cognitive limitations can be a source of explaining the large influence of personal motivations in investment-decisions. Given decision-makers face cognitive limitations, 
they have to rely on other sources of information, or other decision factors when making an investment-decision. For FDI decisions it means human cognition is insufficient to make complicated expected utility calculations, as often used in investment-decision models. It is simply not possible to consider all FDI possibilities available, which means considering all countries in the world as possible host countries. Thus, several choices in order to limit the possible investment alternatives have to be made before even considering an analysis in order to keep the choice options within the boundaries of human cognition. Network theories and experience or learning theories can offer tools for firms to make an investment-decision.

Network theory is based on the idea that there is an economic value attached to the social network you have $e^{\text {iii }}$. The structure of relations among people and organizations in a market can affect or even replace information. Having a network of contact persons, relatives and friends or business relations in a country directly provides a firm with sources of information. Experience and learning theories can provide another tool to deal with cognitive limitations ${ }^{\text {iv }}$. Having experience with the host country directly or indirectly enables a firm to evaluate the experiences and use this knowledge to make the current choices. All information sources and experience the firm has in or about the host country, in the form of networks, experience and knowledge will lead to a better investmentdecision. Where human cognitive fails to understand and analyze all investment possibilities, those factors help the firm to make informed decisions by relying on the network of people that can assist you during the investment period and trusting the knowledge obtained during previous experiences.

The concept of bounded rationality can be extended to include information costs. The decision-maker not only considers the additional information when making a decision, but also takes the costs of collecting information into account during the decision-making process. This theory is known as meta-rationality (Wadeson, 2000)

\subsection{Defining emotions}

So far the economic explanations, rational and bounded rational, focus on the FDI decision-making process. The decision and the decision rules are placed central in by these theories. However, psychological literature suggests there are also psychological factors influencing the decision-maker, as such influencing the firms choice to invest or not. Such psychological aspects remain largely absent from the decision models. In this section one aspects of psychological decision-making influencing the decision-maker, emotions, is introduced as possible source of explanation of FDI decisions.

Within the literature there is no consensus on the definition of emotion, each researcher generally defines its own working definition of emotions. For this article a commonly used definition is adopted, that is suitable for the economic application and abstains from the psychological specifications. Emotions are multifaceted processes that unfold over time. Emotions are manifest in multiple channels and the channels themselves are loosely coupled and interact in a complex way (Venables, 1986, Larsen and Fredrickson, 1999). ${ }^{\mathrm{v}}$ Emotions are both psychological and physiological and include subjective experiences, facial action, central or peripheral nervous system activation, cognitive changes and behavioral action tendencies. ${ }^{\mathrm{vi}}$ Emotions cannot be directed or prevented, people undergo emotions, without tools to resist them. ${ }^{\text {vii }}$ There are two kinds of emotions, visceral and anticipated. Visceral emotions are immediate emotions that occur at the time of the decision, like anger or happiness. Anticipated emotions occur after the decision is made, like for instance regret. Visceral emotions are thus more important when making an investment-decision. Economists more often use anticipated emotions, even though visceral emotions are basic to daily life functioning and decision-making. They are often linked to consumer theories, testing for instance to what extent consumers regret their purchase. Visceral emotions play an essential role in human behavior, but face two major complications. First, they often make people behave in ways that are not necessarily beneficial for them and second, people underestimate the effect of visceral factors on their own current and future behavior (Loewenstein, 2000). ${ }^{\text {viii }}$ 


\subsection{Emotions in economic literature}

The fact that emotions have been largely absent in economic decision theory does not mean that emotions are ignored entirely in modern developments in economic analysis. Emotions are gaining importance and the discussion on inclusion of the concepts in economic theory is becoming more regular (Allen et al., 1992). How individuals behave, feel and make a judgment is considered more and more as a crucial determinant of choices (Kaufman, 1999). Evidently, in the psychological literature, theories on emotions are more popular (see e.g. Lewis and Haviland, 1993; Oatley and Jenkins, 1998; Wollheim, 1999). Specific applications of emotions in economics are found in game theory (Bosman and van Winden, 2002; Duwfenberg, 2002; Selten, 1998) and consumer behavior (Allen et al., 1992; van Dolen et al., 2001; Aaker and Willems, 1998). In other fields, research is done to see to what extent emotions are linked to decisions. Examples are the studies that link happiness and the position in the labor market (Clark and Oswald, 1994; Blanchflower and Oswald, 1992,1998; Oswald 1997) and the analyses that explore the relation between emotions, culture and economic performance (Casson, 1993; Altman, 2001; Gutter et al., 1999) and social cognition (Stajkovic et al, 1998). The conclusion of almost all of these publications is that emotions are an important significant factor in decision-making.

Inclusion of emotions in economic models or frameworks is rare. Based on the literature we reviewed, the only models integrating emotions and economics are using utility theory, measuring emotions as costs and benefits (Loewenstein,1999; Elster ,1998; Frank, 1988). Loewenstein highlights the fact that people highly value their current emotions and underestimate future emotions when maximizing utility today. He uses utility functions, including consumption and emotional states, to show the difference between what people should be maximizing versus what they are maximizing due to emotions. Translated to firm's investment-decisions, his argument is that entrepreneurs at the moment of their investment-decision behave largely under the influence of their emotion that specific day and underestimate the impact of the future. With respect to decisions under uncertainty, Loewenstein argues that peoples cognitive evaluation of risks often diverge from the emotional reaction to those risks. In other words, a positive country risk rating in an economic analysis does not imply the entrepreneur also personally has to consider the country equally riskless. ${ }^{\text {ix }}$ Elster (1998) states emotions can be seen as psychic costs or benefits, which enter in a utility function. Here the valence becomes important. Valence implies that emotions can be measured on a scale from low to high. Elster uses an example of Becker's analysis to illustrate the economic integration of emotions. Meeting a beggar induces guild of being wealthy yourself, which can be considered a (indirect) cost. In addition, you may give money to the beggar to get rid of the bad feeling, which is a direct cost. Thus, emotion itself can be cost (or benefit), or the emotion can lead to a cost (or benefit). The larger the emotion is, the higher the costs or benefits will be in economic terms. Frank (1988) also translates emotions in cost and benefit terminology. Examples are the costs and benefits of marriage, or the costs and benefits cheating in cooperative ventures. In his appendix he derives a formal version of the commitment model, including payoff functions of honest and dishonest persons engaging in joint ventures, also taking costs of scrutiny into account.

However, none of these economic applications combine both economic motivations for decisions with emotions. They only describe the influence of emotions and indicate how to include them in economics terms, therewith loosing any interaction effects between economics and emotions. Kaufman (1999) and Hanoch (2002) do integrate emotions and economics; their research will be build upon in section 2.4

\subsection{Role of emotions in decision-making}

Even though it becomes more accepted that emotions are influencing decision-making processes of individuals, their inclusion in economic theory, without loosing the values of emotions, is not simple. Standard economic theory on FDI decision processes under uncertainty requires rational agents reviewing options and their probabilities. They should estimate the Net Present Value as the main indicator for future success and finally base (non) investment-decisions on the ranking of the options according to that indicator and the related probabilities. The functionality of the theoretical framework depends crucially 
on two basic assumptions related to the decision-making and decision-maker, namely "given tastes and preferences" and "perfect information". The outcomes of the economic decision-making model is of course a simplification of reality, but leads to interesting conclusions. However, those conclusions are only realized when the simplifying assumptions are considered to hold. The incorporation of emotions into this particular part of theory on the one hand indicates that these assumptions do not always hold, but on the other hand may be interpreted as the safeguards of the theory, as will be argued below.

Stability in tastes and preferences is an important prerequisite for rational choice models to work. What is important is that decision-makers know their tastes and preferences and once identified adhere to the same preference ordering. The concept of a utility curve is based on this stability and known and stable utility curves are a necessity for being able to estimate the outcome of the decisions. The model becomes completely volatile and unpredictable if an investor for example at one moment prefers higher revenues above higher total profit in one particular country, but prefers the opposite the next moment or in another country. This is a strong assumption. It not only requires that all the decision-makers know their preferences (it is a cognitive framework) but also that they do not change them. Emotions do not come in. The assumption of perfect information is equally strong, complex and encompassing. It requires that all the information on all relevant characteristics of the goods is available to all market parties (to all consumers and all producers) and this also requires that perfect information holds even for future markets. The assumption of perfect information seems to be very restrictive and it is hard to understand how any market can ever comply with these conditions. The introduction of emotions will not help us a lot in this context; they complicate the analysis further by introducing non-cognitive elements into the decision-making process and further blurring the assumption of perfect information.

The concept of bounded rationality already recognizes these points of critique and argues that due to cognitive limitations people settle for a sub-optimal satisficing solution. Kaufman (1999) builds on this concept and introduces emotions as an additional source of bounded rationality, besides cognition. He argues that, even though the emotional process is largely explicable in rational term, the behavior caused by emotional states can be irrational. Insufficient or excessive emotions cause sub-optimal decisions or performance. With too little emotional intensity people suffer from insufficient physical and mental arousal to perform optimally, while too much emotions cause a person to be so aroused that thinking and physical self-control become disorganized and this deteriorates performance as well. Applying Kaufman's theory to decision-making, the absence of emotions will lead to worse choices than in the presence of limited degree of emotions, as long as they do not become excessive. However, in Kaufman's approach, emotions can never improve decision-making. They not only lead to weaker performance compared to neo-classical economic solutions, but also lead to a deterioration compared to the bounded rationality solution. Or, as Kaufman states, they add a source of bounded rationality, extending the effect of bounded rationality due to cognitive limitations with additional emotional distortions.

Following the line of reasoning of Hanoch (2002), we would like to turn the argument around and argue that allowing emotions to play a role in the decision-making process actually rescues the rational choice model in a particular way. The basic argument is that, even without emotions, the assumption of stable preferences and perfect information cannot be believed to hold. In other words, there is always imperfect information and tastes and preferences are never stable. Decision makers need a device to deal with instability in preferences and imperfect information. This device is the recognition that emotions exist and are allowed to enter the decision-making process (the cognitive acceptance of emotions). Hanoch (2002) elaborates the stable taste argument in detail. His main point is that emotions can function as a tool to prioritize tastes and preferences. Time, or attention is a scarce resource and people simply cannot analyze all preference decisions. Given in reality preferences are not stable, but fluctuate per situation and over time, adjustments in priorities are constantly made. This can be done in a slow, analytical manner, but also quick, based on emotions and intuition. Hanoch argues these quick decisions are not necessarily the best solutions, even though sometimes they are, but they are satisficing solutions. ${ }^{\mathrm{X}}$ 
A second argument Hanoch makes is that individuals are not "cold calculating machines" and feelings or intuition directly affect and change priorities. And last he argues that people do not have the cognitive ability to calculate future probabilities (calculating what will happen), but instead they imagine what may happen. In this imagination, emotions can play large roles.

With respect to the lack of perfect information, Hanoch argues intuition can serve as a tool to make decisions. We extend this argument for FDI decisions. Foreign direct investment-decisions are based on a process that can be subdivided in different phases. For convenience purposes we distinguish five phases:

1. Start searching for investment opportunities;

2. Select information to consider;

3. Interpret the information collected;

4. Stop searching;

5. Evaluate the options and decide.

In each of the phases perfect information is a near impossibility: it requires that all investment opportunities are considered before taking a decision and this not only at any given moment but also at any given moment in the future. It also requires that all the relevant information is available and collected, interpreted and evaluated by an investor. This is unrealistic. No investor will be able to review all (including the future ones) investment opportunities before making a decision. Nor will an investor be able to grasp the complexity of all the information that becomes available and evaluate it in an internally consistent way. All investors need a device to limit the options and to allow them to make a decision on less than perfect information. This device can be the use of emotions. They can become a functional tool in actually making decisions by helping the investor to limit the review and decision process.

Emotions may trigger off search in some circumstances and withhold investors from searching in others, limiting the alternatives that an investor considers. Emotions may help the investor to interpret the (imperfect) information and emotions finally may assist the investor in deciding when to stop searching or evaluating. Interpreted in this particular way, it is not surprising that emotions are observed to play a crucial role in investmentdecisions. They do not replace calculations or rational considerations; they make them possible by limiting the costs. ${ }^{\mathrm{xi}}$

Emotions can be included in an economic choice model in different ways. The two extreme variations are either not to include emotions and intuition at all in the decisionmaking and only use economic arguments (slow, analytical decisions), or to base a decision only on emotions or intuition and exclude any economic arguments (quick emotional decision). More likely are combinations in decision-making, using both aspects. The decision-maker then takes economic and emotional aspects of a decision into account and together they determine the outcome of the decision.

A less direct way for emotions to be involved in decision-making is by influencing all other variables determining the final decision. Limiting the number of variables and estimating a value of economic indicators used in a calculation is not a uniformly decided procedure for all decision-makers. Different variables will be selected by different individuals and interpreted differently. Emotions can then be used as a tool to deal with imperfect information in order to limit the information and will also influence interpretation of the variables, for instance through imagination. An example is valuation of an indicator, which is nominally equal for all decision-makers, like for instance the GDP of a country. The valuation and interpretation still varies per decision-maker and depends very much on the emotion of the decision-maker. What one person will consider as a sufficiently high GDP, can be an insufficiently low GDP for another decision-maker.

It is impossible to say if emotional decisions will lead to more successful decisions than a decision following only economic arguments. The main question is if the two can even be considered separately. Emotions do influence decision-making and empirical research almost always points out that emotions are influential and significant. It is thus hard to explain that emotional behavior has not been included in direct decision-making models so far and empirically the impact of emotional factors on direct investment-decisions has not been tested. In the third section of this paper we will therefore model a decision-making framework that includes both business economic decision-making factors and emotional 
influences.

\section{A decision-making model including an emotional coefficient}

The principle of a utility maximization model is followed, in which individuals are considered rational in economic sense, meaning they are utility maximizing. We realize the inconsistency here, in using a rational neoclassical model, based on assumptions we earlier called unrealistic. However, in section 2.4 we argued exactly that emotions could be the tools to make models work given that the assumptions are not realistic.

In this model the investment-decision of a firm is based both the utility of the firm and the utility of the decision-maker. These two components are separately included in the additive utility function. Emotional influences will be present in both parts of the function

$$
\max . \mathrm{U}(\mathrm{FDI})=\mathrm{U}(\text { firm })+\mathrm{U}(\text { decision-maker })
$$

The rational analytical decision-making variables are included in the first part of the utility function, for instance by defining the highest utility of the firm as the investment possibility with the highest Expected Net Present Value. Thus, U(firm) can be replaced with $\mathrm{U}(E(N P V))$, where firms will invest as soon as the expected NPV is positive. ${ }^{\text {xii }}$ Emotions inherently influence the valuation of NPV, given that emotions are used to select investment alternatives, information sources, value indicators and make future prognoses or imaginations. The utility based on the expected net present value is visualized in figure one.

\section{INSERT FIGURE ONE ABOUT HERE}

The utility is positive (negative respectively) when the $E(N P V)$ is positive (negative). The marginal utility curve of $\mathrm{E}(\mathrm{NPV})$ is always positive, increasing when the $E(N P V)$ is negative, highest when $E(N P V)=0$ and afterwards declining towards zero.

The factors determining the utility of the decision-maker are less clear. ${ }^{\text {xiii }}$ Imagine an entrepreneur who considers to invest in Poland or not. The "business part" of the decision, being the profit expectations, is already incorporated in the utility of the firm. The "personal preferences" of the businessman are included in the utility of the decisionmaker. If the entrepreneur wants to go to Poland, enjoys living abroad and believes he will be successful, he will have a high positive utility, higher than his personal utility of not investing. If on the other hand the businessman has a family that does not want to join him to Poland, he has sad feelings when considering investing and his personal utility of not investing will be higher. While intuitively clear, the most important problem is how to measure these personal preferences. How do you specify emotions and the intensity of emotions (see for instance Larsen and Fredrickson, 1999; Van Dolen et al., 2001; Blamey, 1998; Bosman and van Winden, 2002)? In general, each study selects a number of emotions, which are specifically related to their research. Emotional variables that could be included in the investment-decision-making function are for instance variables related to Emotional Intelligence (instinct, intuition), Emotional Involvement (interest, love, hate), Self-Efficacy (confidence and trust), Individual Experience and Individual Relations (trust, comfort, familiarity, safety). These factors will therefore be introduced in the empirical section of this article. However, how to measure those factors and how to transform them to interpretable variables is a difficult issue.

In order to make the utility of the decision-maker comparable to the utility of the expected NPV, the inputs in the utility function of the decision-maker, here called emotions $(\varepsilon)$, need to be translated into money value. By dividing the utility of the emotions over the marginal utility of money $(M)^{\mathrm{xiv}}$, an Emotional Coefficient (EC) displays the additional revenue in money terms a decision-maker gets due to emotions (see equation two).

$$
\mathrm{EC}=\mathrm{U}(\varepsilon) / \mathrm{U}^{\prime}(\mathrm{M})
$$

The utility of emotions $U(E C)$ is visualized in figure 2a,b and c. Figure 2a describes the 
size of emotions, when taking the size of a firm into account. The larger a firm is, the smaller is the influence of emotions on the decision-making. A small firm has only one decision-maker that is personally affected by the decision. The emotions of the decisionmaker will weight more heavily during the decision-making process, than if a decision is taken by a large multinational corporation, following a standard investment procedure. The same downward slope exists for the utility of money. Smaller firms have less money available, they will have a larger utility of money than larger firms. Thus, the marginal utility of money will be declining as firms increase in size, but will remain positive (see figure $2 b)$.

\section{INSERT FIGURE TWO ABOUT HERE}

Combining emotions and the marginal utility of money in the utility function of emotions, $U(E C)$, these two effects level out for small and large firms. Small firms will have a higher level of $\varepsilon$, but also a higher level of $U^{\prime}(M)$ and large firms will have lower influences by emotions, but also a lower marginal utility of money. Therefore the utility function of emotions will be increasing with positive emotions, but with diminishing returns. ${ }^{\mathrm{xv}}$ Including these specifications in equation one gives

$$
\mathrm{U}(\mathrm{FDI})=\mathrm{U}(\mathrm{E}(\mathrm{NPV})+\mathrm{U}(\mathrm{EC})
$$

Considering the additive utility function (equation one) adding the utility functions of the $E(N P V)$ (figure one) and the emotional coefficient (figure 2c), a firm will only invest if either both utilities are positive, or if one of the two factors is dominating positively.

The theory thus coincides with the literature described in section 2.4. If an investmentdecision is taken following the rational, slow approach, the decision is based only on the utility obtained from the economic calculations. In this model that would mean that $U(E(N P V))$ is the sole factor in decision-making and $U(E C)$ is not considered. If, on the other hand, the quick, emotional approach is taken, $U(E C)$ is the sole factor of decisionmaking and economic calculations are not valued. More likely is the scenario that economic calculations and emotional influences jointly determine decision-making. If $U(E(N P V))$ and $U(E C)$ are both positive or both negative, the decision to invest or not will not be hard. If however $U(E(N P V)$ and $U(E C)$ are of contradicting sign, the decision will be more uncertain. ${ }^{\text {xvi }}$

Interactions between the two utility factors are also possible. If the utility from emotions $U(E C)$ is strongly positive, these strong positive emotions could positively influence business-economic perspective of the market as well. Equally, if a high expected NPV can give the decision-maker happy or exciting feelings. To include interaction effects in the model, an interaction effect containing $U(E(N P V) * E C)$ can be added to the model.

In section four these theoretical possibilities of investment-decisions including emotions will be tested. The tests will first show if the presence of emotional quick decision-making exists in large investment-decision like setting up an FDI. Second will be checked whether emotional variables are indeed, besides economic variables, included in the investment-decision-making. And last we will look whether the presence of emotions has a positive or negative influence on decision-making.

\section{Empirical test of the impact of emotions on decision-making}

In both the literature overview in section two and model in section three we claim emotions play an important role in decision-making. In this section we use a dataset of Dutch firms to empirically test whether emotions play a significant role in their investment choices.

\subsection{The database}

In 2000 a survey has been undertaken among 1592 Dutch firms that had participated in a seminar on investments in Central and Eastern Europe or the former Soviet Union (CEEC and FSU) between 1990 and 2000. Those firms did not necessarily have an investment in the region by the time they were participating in the survey, but they had an 
interest in investing in the region. 23.4 percent of the companies responded to our survey. For this analysis only those firms that seriously considered investing in a direct investment during 1989-1999 were included, in total 219 firms, among which 79 investors in the CEE region and 140 non-investors in the CEE region. ${ }^{\text {xvii }}$ A non-response bias analysis indicated there was a small response bias in favor of larger older firms and firms with an investment in the CEE region. In order to take this into account, the analyses of the data are done with and without correction for this non-response bias. In this article the unweighted results are displayed, in which each observation is weighted as one. In the tables in appendix one both the unweighted and weighted results are shown. A comparison of the weighted and unweighted results shows no significant differences.

\subsection{The results}

The survey included several questions that could shed light on the so-called noneconomic or personal motivations entrepreneurs have when making an investmentdecision, as well as the frequency these factors are indeed influential in the decision. Presence of such personal motivations means a channel for emotions to influence investment-decisions. Appendix two includes the questions which answers are discussed in this section. Question 21 asked firms if they made an investment analysis. Firms were free to define for themselves what to consider an analysis and were asked to mention as well if they made it for one or several countries. 59 percent of the firms did not make any investment analysis. For non-investors this percentage is higher than for the investors (75 percent versus 28 percent respectively). ${ }^{\text {xiil }}$ This large percentage of non-investors not making an analysis is partly the result of the 168 firms that indicated they did not even consider an FDI in the CEE region, either because they were not interested in an FDI or because they were not interested in investing in the CEE region. The reasons mostly mentioned why firms did not make any investment calculation were:

- They were not interested in an FDI in general.

- They were not interested in the CEE region to invest in.

- They had already personal relations with individuals in the respective country.

- They received an invitation of a business partner in the host country to invest in their company or extended existing business relations with a business partner.

- Investing was a logical result after opening of the market and growth of the market.

- The country was the only possibility to invest in due to availability of certain natural resources.

From this question becomes evident that many firms do not use investment analysis as a tool for decision-making. They have other motivations why to invest or not, and know without further research whether they want to invest or not.

The second question, question 23 in appendix two, is an open question. The participating companies that did make an investment analysis could specify the four most important actions/steps during their decision-making process. Given the question was raised as an open question it led to a large variety of answers. The choice of country or location and doing a market/company analysis are clearly important factors in the decision-making for both investors and non-investors. Previous business relations and contacts in the country are quite often mentioned as well as separate motivation to consider in the investment process. More surprising, investors often mention personal motivations; 12,5 percent of all investors indicated one important factor in their decisionmaking was of a clear personal nature. This is even more remarkable given the fact that of the firms that finally did not invest, no personal motivations were given by any of the respondents. Personal contacts and personal experience with a country were mentioned by a significant amount of the both investors and non-investors, indicating these aspects as important in their decision-making process. The results highlight that companies that do make an investment analysis also incorporate personal related variables in their decisionmaking process. The personal motivations are more often mentioned by the firms that did invest, which could mean that personal motivations can be of importance in the investment 
choice in the case of FDI decision. In other words, it seems that once there is a personal motivation, the chance the investment is made is much higher. We test that hypothesis later on in this paragraph.

The third closed question from the questionnaire among Dutch businesses was included to test whether some specific personal factors play a role in decision-making analysis. All firms that seriously considered an investment in the CEE region, irrespective whether they finally invested or not, were asked if several personal variables influenced their decision regarding their investment in the region. If these factors are marked as important, personal motivations do influence decision-making. If they are marked significantly more by those firms that did invest in the CEE region than by non-investors, it is an indication that personal motivations positively influence foreign direct investment-decisions in this region.

- The personal variables included in the question were:

- Having an available contact-person in the country.

- The owner or an employee of the Dutch firm, or the partner, family, friends or relatives of the owner have the nationality of the host economy.

- The owner or an employee of the Dutch firm, or the partner, family, friends or relatives of the owner are willing to work in the host country.

- There is language knowledge available within the firm.

- The owner has positive personal experiences with the country in which the firm considers to invest.

Several of those variables, specifically number one and two, are related to having personal relations or a network in the host country. Having a network not only means having a source of information provision for the firm. It also positively influences the feelings of the decision-maker. Having relations in a country can for instance result in a more secure feeling with respect to the investment. Having the nationality of the host country also implies there is always a personal involvement with that specific country. Again, besides all the economic benefits of having networks and experience with the country, the emotional involvement with respect to the investment-decision is probably a lot higher. Likewise, if an individual is personally interested in spending time in the host economy, the outcome of the investment-decision will personally affect the individual and this influences the final decision. There will be some degree of self-efficacy as well. If a person considers working in the country himself, he or she is very likely convinced of the success of the investment. Language knowledge will probably also lead to a larger selfefficacy. This self-efficacy is likely to positively stimulate the development of building a network sooner and deal with processes and institutions more easy. Positive personal experience increase the involvement of an individual with the country. This results in more positive images when thinking about the country and thereby also feel more confident in engaging in an FDI there.

Table two in appendix one shows the numbers and percentages of firms that responded to each of the above mentioned variables. The variable "contacts in the CEE region" is of crucial importance in the decision-making process. Almost 70 percent of all firms answered that having contacts in the region was a specific reason for their company to choose the country they were considering. Positive experiences, language knowledge and family or friends from the region also play important roles in the decision-making process. Firms that did invest in the region indicate more often that personal variables influenced their decision. However, for none of the variables the difference between investors and non-investors was significant. ${ }^{\text {xix }}$

So far, all three tests indicate that personal factors are important in the decision-making process. First, personal motivations could be a reason for firms not to make any investment calculation. Second, if firms do make an investment calculation they often do include personal related variables in their calculation. Thus, it is interesting to test whether or not personal variables do influence the final investment-decision. Is it fair to say that those firms that do have some personal link with the investment are also more likely to set up an FDI in a transition country?

In order to check that we created four different personal coefficients dummy variables. The variable no analysis is a dummy variable, which is 0 in case companies made an investment analysis and one if they made no analysis but made the decision based on other 
factors. In addition there are three personal variables to indicate the extent to which personal influences were included in a decision-making analysis. In appendix one we included a description how those personal variables were composed. The control variables included are a sector variable ${ }^{\mathrm{xx}}$, age of the Dutch firm at the time if the FDI decision ${ }^{\mathrm{xxi}}$ and size of the Dutch firm measured in number of employees at the time of the FDI decision $^{\text {xxii. }}$. The results of the logit analysis displayed in table four include the results of the unweighted analysis. With respect to the dummy variables capturing personal influences, the difference between the unweighted analysis and weighted analysis included in appendix one in terms of size of the coefficients is considerable, but there are no changes in significance of the variables. The interpretation of the coefficients thus remains the same. .xiii $^{\text {. }}$

Table 1: Logit analysis on who invests in the CEE region and who does not

\begin{tabular}{|c|c|c|c|c|c|}
\hline & Model 1 & Model 2 & Model 3 & Model 4 & Model 5 \\
\hline & Basic & $\begin{array}{l}\text { No } \\
\text { Analysis }\end{array}$ & Personal1 & Personal2 & Personal3 \\
\hline \multirow[t]{2}{*}{ Agriculture } & 0.274 & 0.446 & -0.044 & -0.255 & -0.081 \\
\hline & $(0.59)$ & $(0.93)$ & $(0.09)$ & $(0.47)$ & $(0.15)$ \\
\hline \multirow[t]{2}{*}{ Construction } & -0.296 & -0.129 & -0.312 & 0.070 & 0.838 \\
\hline & $(0.48)$ & $(0.20)$ & $(0.47)$ & $(0.10)$ & $(0.94)$ \\
\hline \multirow[t]{2}{*}{ Transport } & 1.210 & 1.149 & 1.146 & 1.385 & 1.477 \\
\hline & $(2.22)^{*}$ & $(2.04)^{*}$ & $(2.03)^{*}$ & $(2.25)^{\star}$ & $(1.94)$ \\
\hline \multirow[t]{2}{*}{ Trade } & 0.172 & 0.152 & 0.065 & 0.258 & 0.143 \\
\hline & $(0.42)$ & $(0.36)$ & $(0.15)$ & $(0.54)$ & $(0.28)$ \\
\hline \multirow[t]{2}{*}{ Other } & 1.110 & 1.132 & 0.839 & 0.822 & 0.819 \\
\hline & $(2.18)^{\star}$ & $(2.17)^{\star}$ & $(1.55)$ & $(1.38)$ & $(1.27)$ \\
\hline \multirow[t]{2}{*}{ Age } & -0.014 & -0.012 & -0.013 & -0.013 & -0.009 \\
\hline & $(2.41)^{\star}$ & $(2.13)^{*}$ & $(2.21)^{*}$ & $(2.14)^{*}$ & $(1.38)$ \\
\hline \multirow[t]{2}{*}{ Size } & 0.000 & 0.000 & 0.000 & 0.000 & 0.000 \\
\hline & $(1.43)$ & $(1.57)$ & $(1.60)$ & $(1.92)$ & $(2.65)^{\star \star}$ \\
\hline \multirow[t]{2}{*}{ No analysis } & & 1.359 & & & \\
\hline & & $(3.40)^{\star *}$ & & & \\
\hline \multirow[t]{2}{*}{ Personal1 } & & & 1.640 & & \\
\hline & & & $(4.26)^{\star \star}$ & & \\
\hline \multirow[t]{2}{*}{ Personal2 } & & & & 2.353 & \\
\hline & & & & $(6.70)^{\star \star}$ & \\
\hline \multirow[t]{2}{*}{ Personal3 } & & & & & 3.771 \\
\hline & & & & & $(6.91)^{\star \star}$ \\
\hline \multirow[t]{2}{*}{ Constant } & -0.445 & -0.754 & -0.731 & -1.432 & -3.171 \\
\hline & $(1.46)$ & $(2.31)^{\star}$ & $(2.26)^{*}$ & $(3.76)^{\star \star}$ & $(5.23)^{\star \star}$ \\
\hline Pseudo R2 & 0.068 & 0.1093 & 0.1346 & 0.2476 & 0.3849 \\
\hline
\end{tabular}

Source: Survey Dutch Direct Investment in CEEC and FSU, Maastricht University, 2000

225 observations

1) The sector industry is taken as baseline sector.

* significant at 10 percent, ${ }^{* *}$ significant at 5 percent, ${ }^{* *}$ significant at 1 percent

Five different versions of the regression are included. The first model only has control variables and the additional four models each include one of the four dummy variables for personal influences. The main conclusion is that personal influences do have a positive significant impact on the decision-making, meaning that those firms that indicated personal factors played a role have a higher chance of being investors. In the basic model (Model one) the only significant control factors are the variables sector and age of the firm. Firms operating in the sectors transport and other are more likely to invest in the 
CEE region than firms in the sector industry. Age influences the investment-decision negatively, indicating that older firms are less likely to invest in an FDI in a transition country than younger firms. In model two is tested whether a decision without making an investment analysis increases the chance a firm will invest in the CEE region. Indeed this is the case, since the coefficient of the variable no analysis is positive and significant at a five percent level. So firms that did not make an investment-decision based on an analysis but decided based on other motivations, are more likely to invest in an FDI in the CEE region. For the personal variables included in the decision-making analysis (Model three, four and five), irrespective the definition used, the coefficient of the variable personal is always positive and significant at a five percent level. The model with the best explanatory power is Model five, where personal influences are defined least strict.

Concluding, the analysis indicates that personal influences indeed have a positive influence on the investment-decision. If personal aspects are present, firms are more likely to invest in the CEE region than those firms that did not indicate personal factors played a role in their decision-making.

\section{Conclusion}

Emotions are still largely absent in economic theory, though the inclusion of emotions in for example game theory or consumer behavior theory is becoming more current. However, in decision-making theories emotions are still not often included. This finding is surprising given that studies on emotions indicate that in reality they influence decisions and that they can be considered a tool to ease difficult decision-making problems.

In section two a theoretical framework is given to what extent emotions can be included in decision-making and at what points it is conflicting with the current microeconomic theories. We conclude that, instead of seeing emotions as a conflicting variable in economic decision-making, it can also be used as a mechanism to make these economic theories more functional. Emotions can for instance be considered a tool to limit the information to be reviewed in the decision-making process, if information provision is too elaborate to include in an analysis. In addition they also influence the evaluation of certain indicators or choices to be made. Section three provides a simple microeconomic model, based on utility maximization of both the firm and the decision-maker. It includes both economic decision-making variables and an emotional coefficient. Section four gives the result of an empirical test, using data from a survey among Dutch investors making an FDI decision to invest in Central or Eastern Europe or not (CEE region). The results in general indicate that personal motivations are in fact present in the decision-making process, both through the existence of quick - emotional - decision-making instead of a rational slow approach and through the inclusion of personal variables in the decisionmaking analysis. Given personal influences are a channel for emotions to influence decisions, the data show there is reason to accept emotions influence investment-decisions of firms. The results indicate that emotions were more often considered by firms that afterwards did invest in the CEE region, than with firms that decided not to invest. A logit analysis was performed to see whether the reverse was also true, that the presence of emotional influences increases the chance that a firm will invest in the CEE region or not. Using several specifications for the variable personal influences, all models showed that indeed the personal influences had a positive and significant influence on decisionmaking.

Naturally, this research was just a first attempt to include emotions in decision-making theory. The theoretical part only included a first step to incorporate emotions in FDI decisions, keeping the model rather limited. The empirical results should be treated with care as well, given that the measurement of emotions is a complicated issue. However, the results allow to say that emotions are of importance in decision-making. Future research, to both the theoretical embedment in economic theory and empirical tests to the influence of emotions is needed. Further research can shed more light on the value added of inclusion of emotions in economic decision-making models, which again can lead to better explanatory power of the actual decision-making processes of firms. 
Figure 1 Utility function Net Present Value

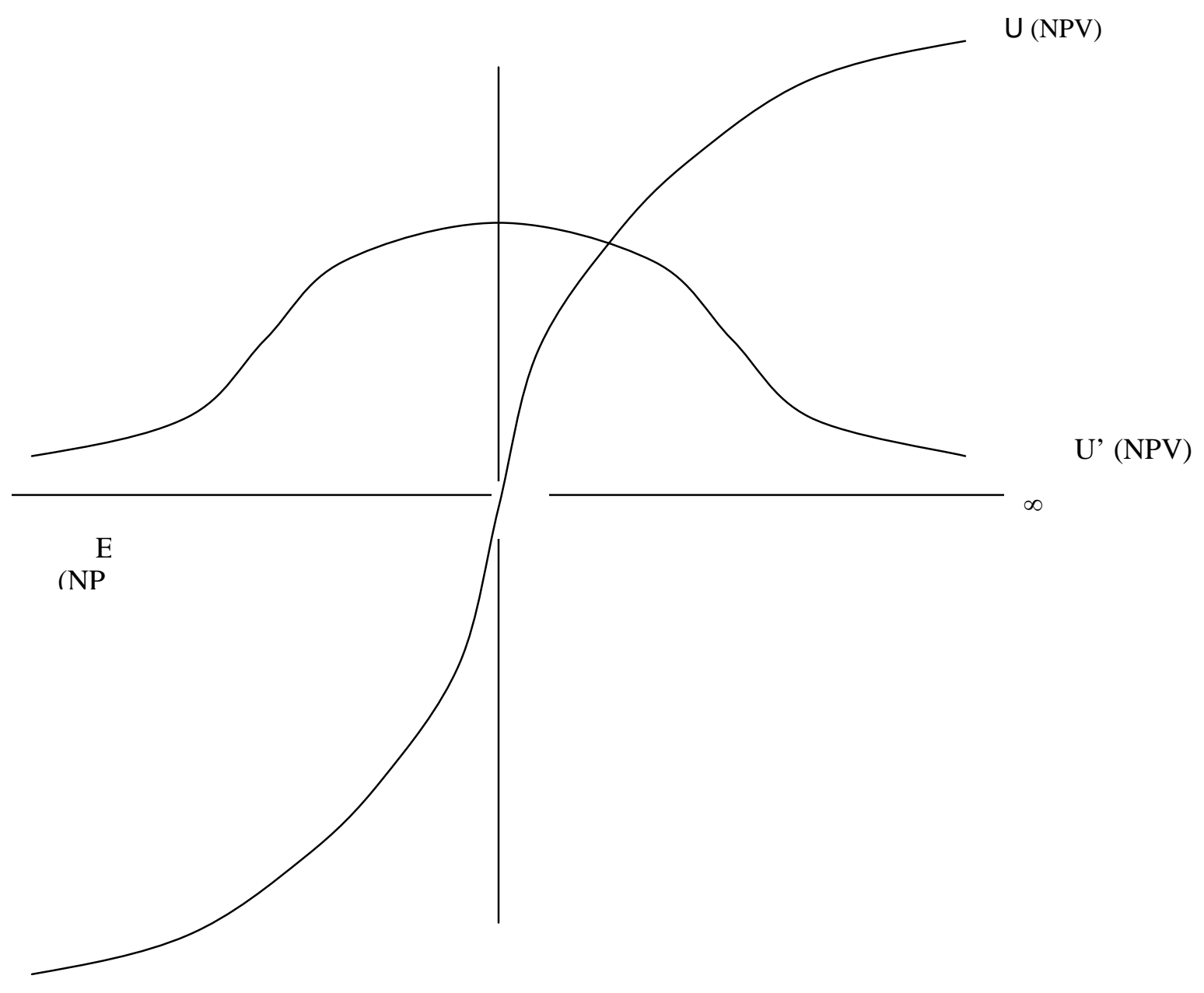


Figure 2: Utility function Emotional Coefficient

Figure 2a

Figure 2b
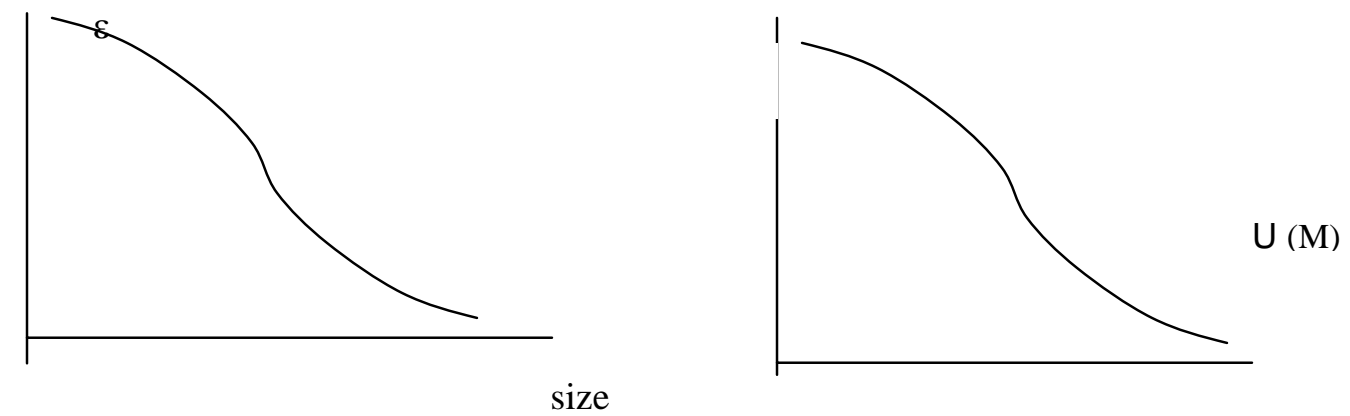

Figure2c

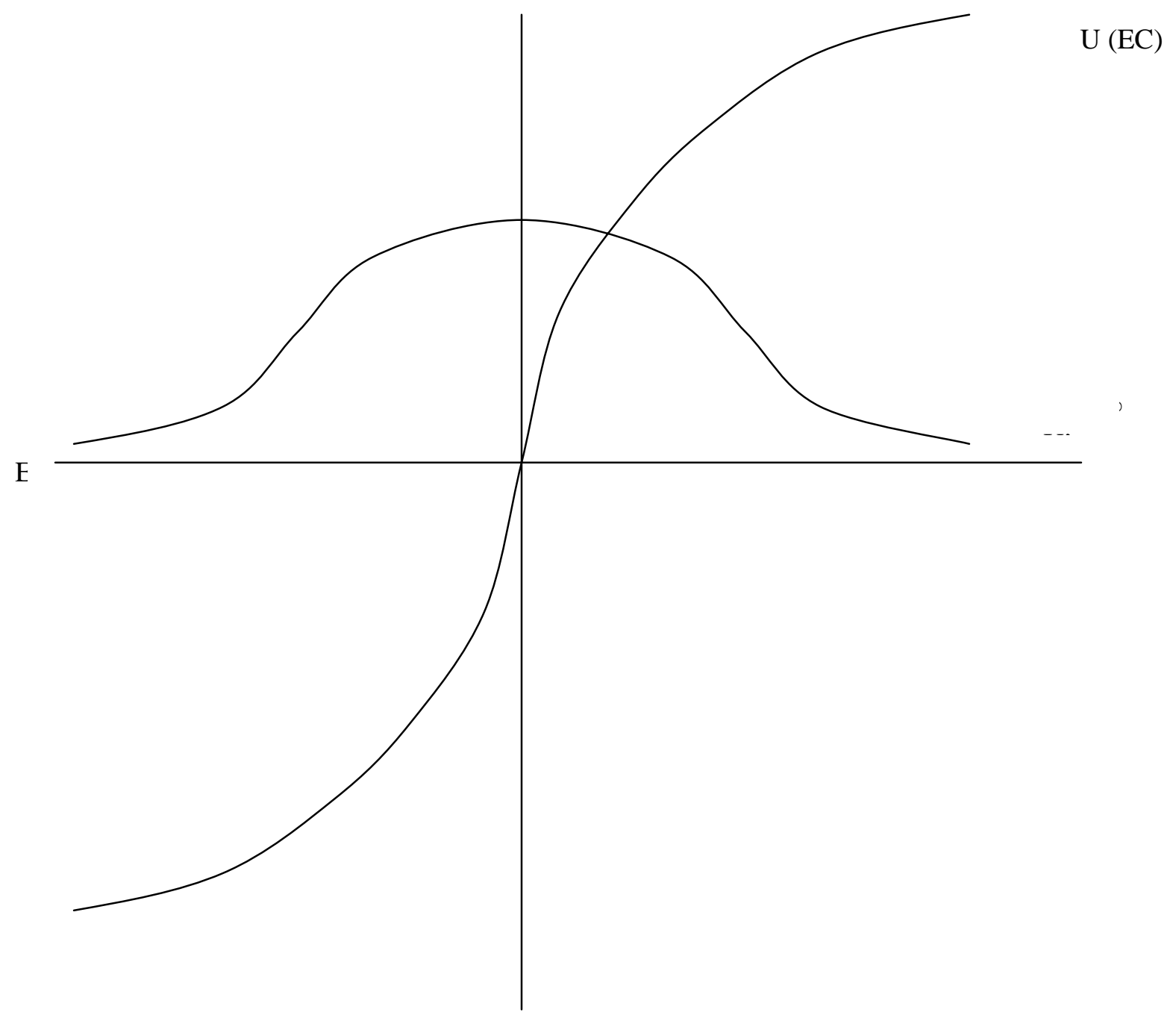




\section{Bibliography}

- $\quad$ Aaker, J. and P. Williams, Empathy versus pride: the influence of emotional appeals across cultures, Journal of consumer research, 25, 1998, pp. 241-261

- $\quad$ Allen, C. T., K.A. Machleit and S. Schultz Klein, A Comparison of Attitudes and Emotions as Predictors of behaviour at Diverse Levels of behavioural Experience, Journal of Consumer Research, 18, 1992, pp. 493-504

- $\quad$ Altman, M., Culture, human agency and economic theory: culture as a determinant of material welfare. Journal of Socio-economics, 30, 2001, pp. 379-391

- $\quad$ Becker, G.S., The economics of discrimination, $2^{\text {nd }}$ ed., Chicago: University of Chicago Press, 1971

- $\quad$ Becker, G.S., The economic approach to human behaviour, University of Chicago Press, 1976

- Blamey, R. K., Decisiveness, attitude expression and symbolic responses in contingent valuation surveys, Journal of Economic Behaviour \& Organisation, 34, 1998, pp. 577-601

- $\quad$ Blanchflower, D.A. and A.J. Oswald, Entrepreneurship, Happiness and Supernormal returns: evidence from Britain and the USA, NBER working paper 4228, Cambridge, USA, 1992

- $\quad$ Blanchflower, D.A. and A.J. Oswald, What makes an entrepreneur?, Journal of Labor Economics, 16 no 1, 1998, pp. 26-60

- Bosman, R. and F. van Winden, Emotional Hazard in a power-to-take experiment, The Economic Journal, 112, 2002, pp. 147-169

- $\quad$ Burt, R.S., The Network Structure of Social Capital, Research in Organisational Behavior, edited by R. I. Sutton and B. M. Staw, Greenwich, CT, JAI Press, 2000

- Casson, M., Cultural determinants of Economic Performance, Journal of Comparative Economics, 17, 1993, pp. 418-442

- Clark, A.E. and A.J. Oswald, Unhappiness and Unemployment, The Economic Journal, 104, 1994, pp. 648-659

- Dolen, W. van, J.Lemming, J. Mattsson and I. Rhoen, Affective consumer responses in service encounters: the emotional content in narratives of critical incidents, Journal of Economic Psychology, 22, 2001, pp. 359-376

- Dixit, A. and R.S. Pindyck, Investment under Uncertainty, Princeton University Press, Princeton, New Jersey, USA, 1994

- $\quad$ Duwfenberg, M., Marital investments, time consistency and emotions, Journal of economic behavior and organisations, 48, 2002, pp. 57-69

- $\quad$ Earl, P., The legacy of Herbert A. Simon in economic analysis, vol. 2, Cheltenham, Edward Elgar, 2001

- $\quad$ Elster, J., Emotions and economic theory, Journal of Economic Literature, 36, 1998, pp. 47-74

- Frank, R., Passion with Reason: the strategic role of emotions, Norton, New York, 1988

- $\quad$ Frijda, N., The emotions, Cambridge, Cambridge University Press, 1986

- $\quad$ Gutter, M.S., J.J. Fox and C.P. Montalto, Racial differences in investor decision making , Financial Services review, 8, 1999, pp. 149-162

- Hanoch, Y., Neither an angel nor an ant: emotion as an aid to bounded rationality , Journal of economic psychology, 23, 2002, pp 1-25

- Hanoch, Y., The effects of emotions on bounded rationality: a comment on Kaufman, Journal of economic behavior \& organization, 49, 2002, pp. 131-135

- $\quad$ Kaufman, B.E., Emotional Arousal as a source of bounded rationality, Journal of Economic Behaviour and Organisaton, 38, 1999 pp. 135-144

- $\quad$ Kaufman, B.E., On emotion and bounded rationality: reply to Hanoch, Journal of economic behavior \& organization, 49, 2002, pp. 137-141

- $\quad$ Larsen, R. J. and B. L. Fredrickson, Measurement issues in emotion research, Well Being; the foundations of hedonic psychology, edited by Kahneman, D., E. Diener and N. Schwartz, Russel Sage Foundation, New York, , 1999, pp. 40-60

- $\quad$ Lewis, M. and J. Haviland, Handbook of Emotions, New York, The Guilford Press, 1993 
- $\quad$ Loewenstein, G., Emotions in economic theory and economic behavior, Preferences, behavior and welfare, 90 (2), 2000, pp. 426-432

- Loewenstein, G., E. U. Weber, C. K. Hsee and N. Welch, Risks as feelings, Psychological Bulletin, 127, 2001, pp. 267-286

- $\quad$ Martin, J., Organizational behavior, Thompson Learning, London, 2nd edition, 2000

- $\quad$ Oatley, K and J.M. Jenkins, Understanding emotions, Cambridge, MA, Blackwell Publishers, 1998

- $\quad$ Oswald, Andrew J., Happiness and Economic Performance, The Economic Journal, 107, 1997, pp. 1815-1831

- $\quad$ Simon, H. A., Models of bounded rationality, Cambridge , MA: MIT Press, 1997

- $\quad$ Trigeorgis, L., Real Options: managerial flexibility and strategy in resource allocation: , Cambridge, MIT Press, 1996

- $\quad$ Selten, R., Features of experimentally observed bounded rationality, European Economic Review, 42, 1998, pp. 413-436

- $\quad$ Stajkovic, A.D. and F. Luthans, Self-efficacy and work-related performance: a metaanalysis, Psychological Bulletin 124, , 1998 pp. 240-261

- Wadeson, N., Bounded rationality, meta rationality and the theory of international business, Models of International Business, edited by M. Casson, Edward Elgar Publishing Limited, Cheltenham, UK, , 2000, pp. 94-116

- $\quad$ Wollheim, R., On the Emotions, New Haven, Yale University Press, 1999 


\section{Appendix 1: Analyses using unweighted and weighted survey data}

For the weighted analysis, correcting for the non-response bias, a probability is calculated for each respondent that a firm with certain characteristics would answer the survey. Characteristics used are sector, size and age of the firm. The data are weighted using the inverse probability of response, thus taking the non-response bias into account. For example, the chance that a large industrial firm responds to the survey is 0.2 , or 20 percent. In the unweighted analysis the answers of this firm are included with a weight of 1. In the weighted analysis, the answers are valued with a factor of $1 / 0.2$, so with a weight of 5 .

Table 1: The most important steps of decision-making; unweighted and weighted results

\begin{tabular}{|c|c|c|c|c|c|c|c|c|}
\hline & Investor & & & & $\begin{array}{l}\text { Non- } \\
\text { investor }\end{array}$ & & & \\
\hline & $\begin{array}{l}\text { Number } \\
(n=58)\end{array}$ & $\begin{array}{l}\% \text { of } \\
\text { investors }\end{array}$ & $\begin{array}{l}\% \text { of } \\
\text { investors } \\
\text { choice } \\
\text { options } \\
\text { (232 choice } \\
\text { options) }\end{array}$ & $\begin{array}{l}\% \text { of } \\
\text { investors } \\
\text { choice } \\
\text { options, } \\
\text { weighted } \\
\text { result } \\
\text { (232) }\end{array}$ & $\begin{array}{l}\text { Number } \\
(\mathrm{N}=36)\end{array}$ & $\begin{array}{l}\% \text { of non- } \\
\text { investors }\end{array}$ & $\begin{array}{l}\% \text { of non- } \\
\text { investors } \\
\text { choice } \\
\text { options } \\
\text { (144 choice } \\
\text { options) }\end{array}$ & $\begin{array}{l}\% \text { of non- } \\
\text { investors } \\
\text { choice } \\
\text { options, } \\
\text { weighted } \\
\text { result (144) }\end{array}$ \\
\hline \begin{tabular}{|l} 
Choice \\
country/location
\end{tabular} & 36 & $62 \%$ & $16 \%$ & $16 \%$ & 14 & $39 \%$ & $10 \%$ & $4 \% \downarrow$ \\
\hline Market analysis & 23 & $40 \%$ & $10 \%$ & $9 \%$ & 15 & $42 \%$ & $10 \%$ & $9 \%$ \\
\hline Choice partner & 13 & $22 \%$ & $6 \%$ & $6 \%$ & 15 & $42 \%$ & $10 \%$ & $8 \% \downarrow$ \\
\hline Become operational & 12 & $21 \%$ & $5 \%$ & $5 \%$ & 2 & $6 \%$ & $1 \%$ & $1 \%$ \\
\hline Company analysis & 10 & $17 \%$ & $4 \%$ & $3 \%$ & 15 & $42 \%$ & $10 \%$ & $9 \%$ \\
\hline \begin{tabular}{|l} 
Availability \\
employees
\end{tabular} & 10 & $17 \%$ & $4 \%$ & $4 \%$ & 2 & $6 \%$ & $1 \%$ & $0 \%$ \\
\hline $\begin{array}{l}\text { Previous business } \\
\text { relations }\end{array}$ & 9 & $16 \%$ & $4 \%$ & $4 \%$ & 2 & $6 \%$ & $1 \%$ & $1 \%$ \\
\hline Personal motivations & 7 & $12 \%$ & $3 \%$ & $4 \%$ & 0 & $p \%$ & $0 \%$ & $0 \%$ \\
\hline $\begin{array}{l}\text { Set up legal structure } \\
\text { company }\end{array}$ & 7 & $12 \%$ & $3 \%$ & $2 \%$ & 0 & $0 \%$ & $0 \%$ & $0 \%$ \\
\hline Other & 6 & $10 \%$ & $3 \%$ & $2 \%$ & 6 & $17 \%$ & $4 \%$ & $6 \% \uparrow$ \\
\hline Contacts & 5 & $9 \%$ & $2 \%$ & $1 \%$ & 8 & $22 \%$ & $6 \%$ & $3 \% \downarrow$ \\
\hline Visit country & 5 & $9 \%$ & $2 \%$ & $2 \%$ & 1 & $3 \%$ & $1 \%$ & $0 \%$ \\
\hline Demand from CEEC & 4 & $7 \%$ & $2 \%$ & $3 \%$ & 3 & $8 \%$ & $2 \%$ & $1 \%$ \\
\hline $\begin{array}{l}\text { Choice mode set up } \\
\text { company }\end{array}$ & 4 & $7 \%$ & $2 \%$ & $2 \%$ & 1 & $3 \%$ & $1 \%$ & $0 \%$ \\
\hline Preparation NL & 3 & $5 \%$ & $1 \%$ & $1 \%$ & 4 & $11 \%$ & $3 \%$ & $2 \%$ \\
\hline Experience & 2 & $3 \%$ & $1 \%$ & $1 \%$ & 3 & $8 \%$ & $2 \%$ & $1 \%$ \\
\hline Natural resources & 2 & $3 \%$ & $1 \%$ & $1 \%$ & 2 & $6 \%$ & $1 \%$ & $0 \%$ \\
\hline Negotiation phase & 2 & $3 \%$ & $1 \%$ & $0 \%$ & 1 & $3 \%$ & $1 \%$ & $0 \%$ \\
\hline Costs & 2 & $3 \%$ & $1 \%$ & $1 \%$ & 0 & $0 \%$ & $0 \%$ & $0 \%$ \\
\hline Media & 1 & $2 \%$ & $0 \%$ & $1 \%$ & 4 & $11 \%$ & $3 \%$ & $3 \%$ \\
\hline
\end{tabular}

Source: Survey Dutch Direct Investment in CEEC and FSU, Maastricht University, 2000. 
The first and second column of table one, for both the investors and non-investors, contain the percentages per group. For example, nine percent of the investors mentioned that contacts in the region were an important factor in their decision. The third and fourth column of the investors and non-investors compare the weighted and unweighted results, per answer option. Each firm had four answer possibilities, leading to a total of 322 answer options for investors and 144 answer options for non-investors. The results show, for example, that ten percent of the answers of the non-investors indicated that choosing a country or location for the FDI is an important step in decision-making. The weighted results do not differ a lot from the unweighted percentages, only for four factors for noninvestors the percentage division deviates more than one percent, and for investors there is no deviation between unweighted and weighted percentages larger than one percent.

Table 2: Personal Factors; by investors and non-investors

\begin{tabular}{|c|c|c|c|c|}
\hline \multirow[t]{2}{*}{ Variable } & \multicolumn{2}{|c|}{$\begin{array}{l}\text { Percentage of Investors for } \\
\text { which this variable had impact } \\
\text { on the investment decision }\end{array}$} & \multicolumn{2}{|c|}{$\begin{array}{l}\text { Percentage of Non-investors } \\
\text { for which this variable had } \\
\text { impact on the investment } \\
\text { decision }\end{array}$} \\
\hline & Unweighted & Weighted & Unweighted & Weighted \\
\hline Available contact-person in the country & $69 \%$ & $60 \%$ & $63 \%$ & $76 \%$ \\
\hline $\begin{array}{l}\text { Owner, employee, partner, family, or friend of the } \\
\text { Dutch firm have the nationality of the host } \\
\text { economy }\end{array}$ & $19 \%$ & $19 \%$ & $9 \%$ & $4 \%$ \\
\hline $\begin{array}{l}\text { Owner, employee, partner, family, or friend of the } \\
\text { Dutch firm are willing to work in that country }\end{array}$ & $14 \%$ & $11 \%$ & $14 \%$ & $11 \%$ \\
\hline Language knowledge available & $19 \%$ & $21 \%$ & $20 \%$ & $16 \%$ \\
\hline Positive personal experiences & $33 \%$ & $38 \%$ & $20 \%$ & $11 \%$ \\
\hline
\end{tabular}

Source: Survey Dutch Direct Investment in CEEC and FSU, Maastricht University, 2000

Note: Of the 90 firms included, 56 firms were investors in the CEE region, and 34 were non-investors

Table 2 shows the unweighted and weighted percentage division of personal factors taken into account in the investment decision. The results of the weighted and unweighted analysis are not significantly different. Having a contact person in the host country is the most important personal factor, for both investors and non-investors. For all factors, the percentages of investors that mentioned the factor as important during the decision making are slightly higher than the percentages for non-investors.

Table 3 includes the results of a logit analysis, testing whether the presence of personal influences positively affect investment decisions. Personal influences are included by means of 3 different dummy variables; personal1, personal2 and personal3. The first personal coefficient "personal1" is the strictest one. It is a dummy variable that is only 1 if strict personal motivations are displayed either in reasons for not making an investment calculation $^{\text {xxiv }}$ (question 21), in the open questions ${ }^{\mathrm{xx}}$ (question 22) or in the closed question $^{\text {xxvi }}$ (question 23). The second variable "personal2" is an extension of the first one, but with a less strict definition of the context of personal involvement. The dummy variable is now also taking the value 1 if firms that gave as motivation to consider a certain country for an FDI that they have a contact person in that country, or they were invited by business relations to invest in that country. The third variable, "personal3", also includes all those firms that did not make any investment calculation. This is the least strict variable, allowing for the highest amount of personal influences.

The results of the logit analysis show that, irrespective of the definition used, personal motivations positively influence the decision to invest. This is true for both analyses, unweighted and corrected for non-response bias.

When comparing weighted and unweighted regressions, the variable "trade" changes signs in model two and model three, but the variable is insignificant. The variable other is significant in the unweighted analysis and insignificant in the weighted analysis, in model one and two, and the variable age is significant in the unweighted model four, and insignificant in the weighted analysis. 
Table 3: Logit analysis on who invests in the CEE region and who does not

\begin{tabular}{|c|c|c|c|c|c|c|c|c|c|c|}
\hline & \multicolumn{2}{|c|}{ Model 1} & \multicolumn{2}{|l|}{ Model 2} & \multicolumn{2}{|l|}{ Model 3} & \multicolumn{2}{|l|}{ Model 4} & \multicolumn{2}{|l|}{ Model 5} \\
\hline & Basic & $\begin{array}{l}\text { Basic } \\
\text { weighted }\end{array}$ & $\begin{array}{l}\text { No } \\
\text { Analysis }\end{array}$ & $\begin{array}{l}\text { No } \\
\text { Analysis } \\
\text { weighted }\end{array}$ & Personal1 & $\begin{array}{l}\text { Personal1 } \\
\text { weighted }\end{array}$ & Personal2 & $\begin{array}{l}\text { Personal2 } \\
\text { weighted }\end{array}$ & Personal3 & $\begin{array}{l}\text { Personal3 } \\
\text { weighted }\end{array}$ \\
\hline \multirow[t]{2}{*}{ Agriculture } & 0.274 & 0.196 & 0.446 & 0.314 & -0.044 & -0.072 & -0.255 & -0.292 & -0.081 & -0.026 \\
\hline & $(0.59)$ & $(0.39)$ & $(0.93)$ & $(0.61)$ & $(0.09)$ & $(0.14)$ & $(0.47)$ & $(0.51)$ & $(0.15)$ & $(0.05)$ \\
\hline \multirow[t]{2}{*}{ Construction } & -0.296 & -0.295 & -0.129 & -0.180 & -0.312 & -0.311 & 0.070 & 0.194 & 0.838 & 0.793 \\
\hline & $(0.48)$ & $(0.48)$ & $(0.20)$ & $(0.28)$ & $(0.47)$ & $(0.51)$ & $(0.10)$ & $(0.32)$ & $(0.94)$ & $(0.88)$ \\
\hline \multirow[t]{2}{*}{ Transport } & 1.210 & 1.448 & 1.149 & 1.300 & 1.146 & 1.520 & 1.385 & 1.724 & 1.477 & 1.712 \\
\hline & $(2.22)^{\star}$ & $(2.33)^{\star}$ & $(2.04)^{\star}$ & $(2.26)^{*}$ & $(2.03)^{*}$ & $(2.37)^{*}$ & $(2.25)^{\star}$ & $(2.83)^{\star \star}$ & $(1.94)$ & $(3.64)^{\star \star}$ \\
\hline \multirow[t]{2}{*}{ Trade } & 0.172 & 0.022 & 0.152 & -0.015 & 0.065 & -0.072 & 0.258 & 0.216 & 0.143 & 0.056 \\
\hline & $(0.42)$ & $(0.05)$ & $(0.36)$ & $(0.03)$ & $(0.15)$ & $(0.14)$ & $(0.54)$ & $(0.39)$ & $(0.28)$ & $(0.10)$ \\
\hline \multirow[t]{2}{*}{ Other } & 1.110 & 1.226 & 1.132 & 1.234 & 0.839 & 0.827 & 0.822 & 0.580 & 0.819 & 0.744 \\
\hline & $(2.18)^{*}$ & $(1.78)$ & $(2.17)^{\star}$ & $(1.77)$ & $(1.55)$ & $(1.15)$ & $(1.38)$ & $(0.58)$ & $(1.27)$ & $(0.72)$ \\
\hline \multirow[t]{2}{*}{ Age } & -0.014 & -0.019 & -0.012 & -0.019 & -0.013 & -0.019 & -0.013 & -0.015 & -0.009 & -0.012 \\
\hline & $(2.41)^{*}$ & $(2.05)^{\star}$ & $(2.13)^{\star}$ & $(1.96)$ & $(2.21)^{*}$ & $(2.26)^{\star}$ & $(2.14)^{*}$ & $(1.86)$ & $(1.38)$ & $(1.50)$ \\
\hline \multirow[t]{2}{*}{ Size } & 0.000 & 0.000 & 0.000 & 0.000 & 0.000 & 0.000 & 0.000 & 0.000 & 0.000 & 0.000 \\
\hline & $(1.43)$ & $(0.94)$ & $(1.57)$ & $(1.12)$ & $(1.60)$ & $(0.85)$ & $(1.92)$ & $(1.41)$ & $(2.65)^{\star \star}$ & $(1.98)^{*}$ \\
\hline \multirow[t]{2}{*}{ No analysis } & & & 1.359 & 1.110 & & & & & & \\
\hline & & & $(3.40)^{* \star}$ & $(2.47)^{\star}$ & & & & & & \\
\hline \multirow[t]{2}{*}{ Personal1 } & & & & & 1.640 & 2.156 & & & & \\
\hline & & & & & $(4.26)^{\star \star}$ & $(4.36)^{\star \star}$ & & & & \\
\hline \multirow[t]{2}{*}{ Personal2 } & & & & & & & 2.353 & 2.708 & & \\
\hline & & & & & & & $(6.70)^{\star \star}$ & $(6.02)^{\star \star}$ & & \\
\hline \multirow[t]{2}{*}{ Personal3 } & & & & & & & & & 3.771 & 3.617 \\
\hline & & & & & & & & & $(6.91)^{\star \star}$ & $(5.36)^{\star \star}$ \\
\hline \multirow[t]{2}{*}{ Constant } & -0.445 & -0.310 & -0.754 & -0.513 & -0.731 & -0.731 & -1.432 & -1.594 & -3.171 & -2.935 \\
\hline & $(1.46)$ & $(0.76)$ & $(2.31)^{*}$ & $(1.19)$ & $(2.26)^{*}$ & (1.84) & $(3.76)^{\star \star}$ & $(3.16)^{\star \star}$ & $(5.23)^{\star \star}$ & $(3.97)^{\star \star}$ \\
\hline Pseudo R2 & 0.068 & 0.0811 & 0.1093 & 0.1031 & 0.1346 & 0.2011 & 0.2476 & 0.2973 & 0.3849 & 0.3802 \\
\hline
\end{tabular}

Source: Survey Dutch Direct Investment in CEEC and FSU, Maastricht University, 2000

225 observations

1) The sector Industry is taken as baseline sector.

* significant at 10 percent, ${ }^{* *}$ significant at 5 percent, ${ }^{* *}$ significant at 1 percent 


\section{Appendix 2 Questions related to personal influences included in the survey}

21. Did you make any investment analysis to estimate the possibility of success of the investment?

(only 1 answer possible)

1 [] Yes, only for the country of the $1^{\text {st }}$ investment

2 [] Yes, for the country of our $1^{\text {st }}$ investment and multiple other countries

3 [] No, no calculation was made. The company chose for the country of our $1^{\text {st }}$ investment because:

22. What were the $\mathbf{4}$ most important actions during your decision making process, in chronological order (for instance fist the choice of a country, afterwards the search for an appropriate local partner).

(please enter in each box an action of your investment decision making progress,

in chronological order)

1.

2.

3.

4.

23. Which one of the following aspects was a specific reason for your company to make the investment analysis for the country of your $1^{\text {st }}$ investment?

(multiple answers possible)

1 [] There was already a trade relation with one or more companies in that country

2 [] There was a good contact-person to work with in that country

3 [] Other companies in that sector achieved good results in that country

4 [] The owner or employees of the Dutch firm are from that country

5 [] Your partner or direct family members are from the country of your $1^{\text {st }}$ investment

6 [] Friends or acquaintances are from the country of your $1^{\text {st }}$ investment

7 [] The owner or employees of the Dutch firm were willing to work in the country of your $1^{\text {st }}$ investment

8 [] Your partner or direct family was willing to work in the country of your $1^{\text {st }}$ investment

9 [] Friends or acquaintances were willing to work in the country of your $1^{\text {st }}$ investment

10 [] Language knowledge of the country of your $1^{\text {st }}$ investment in the Dutch firm available

11 [] Positive personal experiences in the country of your $1^{\text {st }}$ investment, for instance because of travel experiences

12

[] Other, namely: 


\section{Endnotes}

' In fact basic economic theory requires three sets of assumptions to hold:

- Limited and given resources, given tastes/preferences and given technology;

- Pure economic goods, perfect information and perfect competition;

- Absence of value judgments;

ii Simon (1997), Models of Bounded Rationality, chapter IV.1.

iii There is "a network if individuals are variably connected to one another as a function of prior contact, exchange and attendant emotions" (Burt, 2000).

iv Cognitive learning theories and social learning theories describe the possible effects of experience (Martin, 2001).

The basis of cognitive learning is that individuals develop cognitive frameworks that allow them to interact more effective in a certain environment. Experience assists the individual in decision-making, determining behavioral options and choosing a certain behavior. Social and experiential learning relates to the idea that within each environment people learn and experience different things and thus automatically learn different things that are attached to that specific social setting.

${ }^{v}$ Being economists, we abstain from the psychological discussions surrounding the concept of emotions and settle for a definition that is commonly used and suitable for this paper, without entering the discussion what to include or exclude.

${ }^{v i}$ Emotions always have an intentional object, being a person or a state of affairs (envy at someone, sad because of something). Emotional states are characterized by hormonal changes and changes in the autonomic nervous system and have characteristic observable expressions (for instance a smile). Emotions can be located on a pleasure-pain scale, including a neutral point of emotional indifference (valence) and often lead to action tendencies (for instance anger and hurting someone, love and touching, shame and hiding) (Frijda, 1986).

vii They can avoid situations in which they know they will face emotions (for example a person that is alcohol addicted can avoid going to bars), or they can equip themselves with strategies to deal with the emotion (for instance angry people often use the "golden rule" count to 10 before responding, instead of responding immediately), but they cannot avoid emotions in itself.

viii Loewenstein (2000) mentions the example of a road-rage. When asked in advance, people recognize that it is not in their self-interest to assault another driver that they find irritating, but in real life emotions do often lead to such assaults. Another example is given by Kaufman (1999) in his illustration of a homosexual man being infected with the HIV virus due to unsafe sex practice. The man admitted it was not in his self-interest to practice unsafe sex, but driven by the emotion of happiness and love this knowledge became less important. Especially in this last example the short-term emotions driving a decision lead to very important consequences.

${ }^{i x}$ It is commonly know that, even though rationally risks remain constant, it feels as if risks become higher when they come closer. For example, a war is more threatening if it is between your neighboring countries instead of at the other side of the world. Equally, a country can have consistent mediate risk ratings, but feels more risky if you have to live there with your family. Or, a bungee jump today is considered scarier than a bungee jump next year, even though the risks remain equal.

${ }^{x}$ An example Hanoch (2002) mentions is an individual walking through the woods with the aim to pick blueberries. At some point this individual encounters a snake and jumps back. At that point the priorities have shifted; instead of picking blueberries, survival became priority number one. The individual did not analytically calculate the costs if jumping back, the probabilities of being bitten and the revenues of having blueberries, but intuitively decided to jump back - the optimal solution.

${ }^{x i}$ See also Wadeson (2000).

xii This NPV decision-making model could in principle be replaced by any other economic decision-making model, such as the option models, without changing the fundamental idea described.

xiii In the case of several decision-makers, the sum of their personal utility can be included here.

${ }^{x i v}$ The model is following the discrimination theory of Becker, 1971.

${ }^{x v}$ The difference between for instance slightly negative, neutral (0) and slightly positive emotions on utility is larger than the difference between positive and very positive emotions. Therefore the marginal utility is positive but small at very negative and very positive levels of EC.

xvi An example of an investment-decision is a manager of a small company that considers investing in Hungary, including the fact that the manager has to move to Hungary. If he expects Hungary to be a profitable market $(U(N P V>0)$ and also is having positive emotions with respect to Hungary, $(U(E C)>0)$, he will definitely invest in the country. However, if the business-economic calculations are positive $(\mathrm{U}(\mathrm{NPV})>0)$ but the manager is totally against living in Hungary $(\mathrm{U}(\mathrm{EC}) \rightarrow-\infty)$, he will decide not to invest.

xvii The selection of firms this survey is taken from a database the Dutch chambers of commerce collected of firm that participated in seminars on investments in transition countries or asked for information materials concerning foreign investments. Inherently this firm selection method results in a bias of respondents compared to the overall population of Dutch firms. The respondents are more interested in international activities and more often are involved in international trade and direct investments than the average Dutch firm. However, given that the purpose of the research is to analyze investment-decision processes of firms, this bias is considered an advantage for this research.

xviii Investors are firms that at the time of the survey had an FDI in the CEE region, non-investors are those firms that were interested in the CEE region, but decided not to invest.

${ }^{\mathrm{xix}}$ For each of the variables a Pearson chi2 test was done, to see whether the data for investors and non-investors are independent. In none of the cases was the difference in outcomes between investors and non-investors significant.

${ }_{x x}$ Six dummy variables are defined using 1-digit SBI code, with Agriculture, including Agriculture (A), Fishery (B) and Natural resources, Industry (D), Construction $(\mathrm{F})$, Transport (I), Trade $(\mathrm{K})$ and Other including $\mathrm{E}$ (Electricity, Gas and Water), H (Hotel, Restaurants), J (Financial institutions), L (Government/NGO), M (Education), N (Health), O (Environment), P (Private households) and Q (Extraterritorial bodies).

xxi All firms older than 100 years are included as being 100 years old.

xxii As primary source the answers from the questionnaire are taken. We included the number of employees of 1989 , 1994 or 1999, depending on which year closest preceded the year of the investment-decision. Whenever data for 
that specific year were missing, we used the number of employees from the later years as proxy.

${ }^{\text {xxiv }}$ The dummy variable is set at 1 if the reasons for not making an investment calculation is a personal one (see table 1)

${ }^{x \times v}$ The dummy variable is set at 1 if in the open question the firms answer fell in the category personal motivations (see table 2)

xxvi The dummy variable is set at 1 if the answer options "the owner, friends or family are from the host country", "the owner, friends or family are willing to work in the host country", "someone from the firm speaks the language of the host country" or "the firm had positive experiences in that country" were marked as motivations for the investment (table 3). 